\title{
MiR203 mediates subversion of stem cell properties during mammary epithelial differentiation via repression of $\triangle N P 63 \alpha$ and promotes mesenchymal-to-epithelial transition
}

\author{
AJ DeCastro ${ }^{1}$, KA Dunphy ${ }^{2}$, J Hutchinson ${ }^{1}$, AL Balboni ${ }^{1}$, P Cherukuri ${ }^{1}$, DJ Jerry ${ }^{2}$ and J DiRenzo ${ }^{\star, 3}$
}

During reproductive life, the mammary epithelium undergoes consecutive cycles of proliferation, differentiation and apoptosis. Doing so relies on the retained proliferative capacity, prolonged lifespan and developmental potency of mammary stem cells (MaSCs). $\triangle N p 63 \alpha$, the predominant TP63 isoform in mammary epithelia, is robustly expressed in MaSCs and is required for preservation of self-renewing capacity in diverse epithelial structures. However, the mechanism(s) underlying subversion of this activity during forfeiture of self-renewing capacity are poorly understood. MicroRNAs (miRNAs) govern critical cellular functions including stem cell maintenance, development, cell cycle regulation and differentiation by disrupting translation of target mRNAs. Data presented here indicate that expression of miR203, a miRNA that targets $\Delta N p 63 \alpha$ and $\Delta N p 63 \beta$ is activated during luminal epithelial differentiation and that this pattern is observed in the murine mammary hierarchy. In addition, we present evidence that the transcription factor Zeb1 represses miR203 expression, thus enhancing $\Delta$ Np63 $\alpha$ protein levels. Furthermore, ectopic miR203 suppresses $\Delta \mathrm{Np} 63 \alpha$ expression, proliferation and colony formation. The anti-clonogenic effects mediated by miR203 require suppression of $\Delta \mathrm{Np} 63 \alpha$. In addition, ectopic miR203 promotes mesenchymal-to-epithelial transition and disrupts activities associated with epithelial stem cells. These studies support a model in which induction of miR203 mediates forfeiture of self-renewing capacity via suppression of $\Delta \mathrm{Np} 63 \alpha$ and may also have anti-tumorigenic activity through its reduction of EMT and cancer stem cell populations.

Cell Death and Disease (2013) 4, e514; doi:10.1038/cddis.2013.37; published online 28 February 2013

Subject Category: Experimental medicine

The majority of mammary gland development occurs after birth and is governed by a precise sequence of hormonal and morphogenic signals that regulate ductal branching and elongation of the nascent mammary gland. ${ }^{1}$ Mammary organogenesis is driven by the mitotic activity and extravasation of the terminal end bud through the stromal fat pad. Following mammary organogenesis and near the completion of puberty, the terminal end bud regresses and the mammary gland enters a stage of regenerative homeostasis characterized by periodic, successive regenerative cycles composed of distinct waves of proliferation and cell death. ${ }^{2}$ This pattern of regenerative stasis relies on the presence and activity of mammary stem cells (MaSCs), which have been prospectively isolated from primary mouse and human mammary epithelial cells. ${ }^{3-6}$ The epithelial portion of the mammary gland is a bilayered ductal system. The inner most layer consists of luminal epithelia that line the mammary ducts and the milkproducing lobuloalveolar units. The basal/myoepithelial layer separates the luminal epithelia from a basement membrane and contains cells that co-express $\Delta \mathrm{Np} 63 \alpha,{ }^{7}$ nestin ${ }^{8}$ and other markers associated with stem cell activity. Several studies have demonstrated that these cells co-enrich with serial mammary regenerative capacity, indicating that the basal/myoepithelial layer may represent a specialized MaSC niche..$^{3,4,9}$

Abundant evidence implicates $\Delta \mathrm{Np} 63$ isoforms in preservation of self-renewal and tissue stasis in diverse epithelial structures, including the mammary gland. Targeted ablation of $\Delta \mathrm{Np63}$ isoforms leads to broad-spectrum epithelial hypoplasias characterized by stem cell depletion and ablated regenerative kinetics. ${ }^{10-12}$ Although the precise mechanisms by which $\Delta \mathrm{Np} 63 \alpha$ preserves self-renewing capacity are not fully understood, substantial evidence indicates that it potently inhibits cellular senescence. ${ }^{13}$ In addition, haploinsufficiency of TP63 confers a premature aging phenotype associated with a sharp increase in cellular senescence. ${ }^{13-15}$ In basal breast cancers and head and neck squamous cell carcinomas, $\Delta \mathrm{Np} 63 \alpha$ acts as a pro-survival factor and a mediator of chemoresistance that actively represses expression of pro-apoptotic effectors. ${ }^{16,17}$ These studies provide compelling evidence that $\Delta \mathrm{Np} 63 \alpha$ is critical for preservation of replicative capacity,

${ }^{1}$ Program in Experimental and Molecular Medicine and the Department of Pharmacology, The Geisel School of Medicine at Dartmouth, Hanover, NH, USA; ${ }^{2}$ Department of Veterinary and Animal Science, University of Massachusetts-Amherst, Amherst, MA, USA and ${ }^{3}$ Department of Pharmacology and Toxicology, The Geisel School of Medicine at Dartmouth, Hanover, NH, USA

*Corresponding author: J DiRenzo, Department of Pharmacology and Toxicology, The Geisel School of Medicine at Dartmouth, 7650 Remsen, Hanover, NH 03755 , USA. Tel: 603-650-1794; Fax: 603-650-1129; E-mail: James.DiRenzo@ Dartmouth.edu

Keywords: microRNA; miR203; p63; Zeb1; mammary stem cells; mesenchymal-to-epithelial transition (MET)

Abbreviations: DIP, Dexamethasone, Insulin, Prolactin treatment; EMT, Epithelial-to-mesenchymal transition; FACS, Fluorescence activated cell sorting; IMEC, immortalized mammary epithelial cells; KRT, Cytokeratin; MaSC, mammary stem cells; MiR-CON, Synthetic microRNA control; MS, mammospheres

Received 30.12.12; accepted 16.1.13; Edited by E Candi 
prolonged life span and survival that are characteristic of adult and cancer stem cells. They further suggest that specific mechanisms exist to subvert these activities during lineage commitment and cellular differentiation.

MicroRNAs (miRNAs) are a class of endogenous small RNA molecules that are approximately 22 nucleotides in length. ${ }^{18}$ MiRNAs govern diverse cellular activities including proliferation, apoptosis, differentiation, development and tumorigenesis by targeting the RNA-induced silencing complex to the $3^{\prime}$-UTR of target mRNAs. ${ }^{19,20}$ MiR203 was identified as a stemness inhibiting miRNA that is highly expressed in the epidermis where it targets $\alpha$ and $\beta$ isoforms of TP63 to promote epidermal differentiation. ${ }^{21,22}$ In addition to its role in normal epithelial biology, miR203 has also been shown to be aberrantly expressed in several types of human cancers including bladder, colon, pancreatic, liver, prostate and lung. ${ }^{23-28}$ Interestingly, miR203 is repressed by the transcriptional repressor zinc-finger E-box binding homeobox 1 (ZEB1), a repressor of multiple key mediators of epithelial differentiation $^{29}$ and a potent activator of epithelial-to-mesenchymal transition (EMT). ${ }^{30}$ EMT is a key developmental program that can be re-activated during cancer development and has been linked to tumor invasion, metastasis and chemo-resistance. ${ }^{31}$ In addition, cancer cells have been reported to utilize EMT to acquire cancer stem cell properties in part through the modulation of miRNAs. ${ }^{32-34}$ These reports implicate miRNAs as mediators of EMT, stemness and the acquisition of an aggressive cancer phenotype. ${ }^{33,34}$ These findings, coupled to reports linking $\Delta \mathrm{Np} 63 \alpha$ to MaSC renewal and breast cancer aggression suggest that miR203 may have important roles in the mammary regenerative hierarchy as well as in breast cancer.

The goal of this study was to determine the functional significance of miR203 in MaSC activity and luminal epithelial cell fate in the mammary gland. Results indicate that expression of miR203 is induced during lactogenic differentiation and increases during luminal epithelial differentiation. Data presented here indicate that in mammary epithelia, miR203-mediated suppression of $\Delta \mathrm{Np} 63 \alpha$ reduces proliferation, clonogenic potential and transcriptional suppression of HBP1, a pro-differentiation gene transcriptionally repressed by $\Delta \mathrm{Np} 63 \alpha^{35}$ In a panel of mammary epithelial and breast cancer cell lines, miR203 expression correlates with the degree of luminal differentiation, as it is lowest in basal/triple negative and highest in luminal-like breast cancer cell lines. Finally, ectopic miR203 expression is able to mediate a mesenchymal-to-epithelial transition (MET) that was associated with a reduction in the cancer stem cell population $\left(\mathrm{CD} 44^{+} \mathrm{CD}^{-} 4^{-}\right)$and an increase in the expression of the luminal cell marker CD24. Together, these studies suggest that miR203 is a potent stem cell regulator and has a significant role in the acquisition of luminal epithelial cell fate through the forfeiture of MaSC activity in the normal mammary gland and breast cancer stem cells.

\section{Results}

Expression of miR203 correlates with differentiation in the mammary epithelium. Substantial evidence indicates that $\Delta \mathrm{Np63 \alpha}$ is required for preservation of MaSCs. However, the mechanism(s) by which this activity is subverted during forfeiture of self-renewing capacity and developmental commitment are not well understood. MiR203 directly targets sequences within exon 15 of TP63 that encode the 3'UTR of $\alpha$ and $\beta$ isoforms. ${ }^{22}$ This finding coupled to the fact that $\Delta \mathrm{Np} 63 \alpha$ is required for MaSC preservation suggests that increased expression of miR203 may promote differentiation in the mammary regenerative hierarchy. To test this, enriched fractions of MaSCs $\left(\mathrm{Lin}^{-} / \mathrm{CD} 24^{+} / \mathrm{CD} 29^{\text {high }} / \mathrm{CD} 61^{+}\right)$, luminal progenitors $\left(\mathrm{Lin}^{-} / \mathrm{CD} 24^{+} / \mathrm{CD} 29^{\text {low }} / \mathrm{CD} 1^{+}\right)$and mature luminal epithelia $\left(\mathrm{Lin}^{-} / \mathrm{CD} 24^{+} / \mathrm{CD} 29^{\mathrm{low}} / \mathrm{CD} 61^{-}\right)$were isolated (Figure 1a) and analyzed for expression of miR203. Cytokeratin profiling of these fractions revealed that $\mathrm{Lin}^{-} /$ CD24 ${ }^{+} / \mathrm{CD} 29^{\text {low }} / \mathrm{CD} 61^{-}$fractions were enriched for the luminal epithelial cytokeratins KRT18 and KRT19 (Supplementary Figure S1a), whereas $\mathrm{Lin}^{-} / \mathrm{CD} 24^{+} /$ CD29high was highly enriched for expression of basal epithelial markers, KRT14 and KRT5 (Supplementary Figure S1b). In addition, GATA3 expression was highest (Supplementary Figure S1c) in mature luminal epithelia $\left(\mathrm{Lin}^{-} / \mathrm{CD} 24^{+} / \mathrm{CD} 9^{\text {low }} / \mathrm{CD}^{-} 1^{-}\right)$, which is consistent with previous studies indicating that expression of CD61 segregates luminal epithelial cells, ${ }^{35}$ and that this progression requires GATA3. ${ }^{36,37}$ Analysis of miR203 levels indicated a sharp increase in luminal progenitors and differentiated luminal epithelial cells relative to the enriched MaSC fraction (Figure 1b). Previous studies have implicated Zeb1 as a potent repressor of miR203 and other miRNAs, and can promote tumorigenic capacity by maintaining self-renewal capacity. ${ }^{38}$ Consistent with these findings, Zeb1 expression was highest in the enriched fractions of MaSCs and declined in committed populations (Figure 1c). To determine if the observed increase in miR203 correlated with a decline in $\Delta \mathrm{Np} 63 \alpha$ protein levels, $\mathrm{Lin}^{-} / \mathrm{CD} 24^{+} / \mathrm{CD} 29^{\text {high }} / \mathrm{CD} 61^{+}$cells and $\mathrm{Lin}^{-} / \mathrm{CD}_{24}{ }^{+} / \mathrm{CD} 29^{\text {low }} / \mathrm{CD} 61^{+}$cells, which enrich for mammary epithelial stem and luminal epithelial progenitor cells, respectively, were stained for total p63. Results indicate that p63 is robustly expressed in the enriched fractions of MaSCs and undetectable in the luminal progenitors (Figure 1d). Finally HBP1, a pro-differentiation HMG-box transcriptional regulator ${ }^{39,40}$ whose expression is repressed by $\Delta \mathrm{Np} 63 \alpha$ was observed to increase with differentiation (Figure 1e). Together, these data support a model in which Zeb1 represses miR203 expression thereby preserving $\Delta \mathrm{Np} 63 \alpha$ expression in MaSCs and that this repression is relieved during the loss of self-renewing capacity. Consistent with this model, we noted a strong correlation between miR203 levels and the degree of differentiation in breast cancer cell lines (Figure 1f and Supplementary Figure S1D).

MiR203-mediated suppression of $\triangle N P 63 \alpha$ is required for lactogenic differentiation. The previous data demonstrate a correlation between miR203 expression and differentiation in the mouse mammary epithelium as well as in breast cancer. To determine if miR203 expression is induced during luminal epithelial differentiation and to determine the role of Zeb1 in this process we adopted an established luminal differentiation system in which the immortalized murine mammary epithelial cell line, HC11 is first deprived of EGF and then treated with dexamethasone, insulin and prolactin 


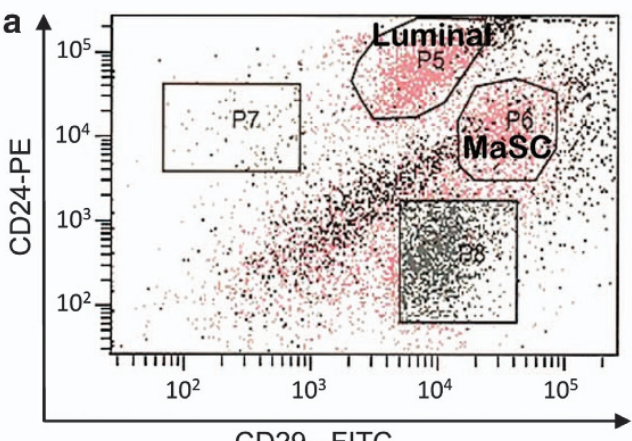

CD29 - FITC

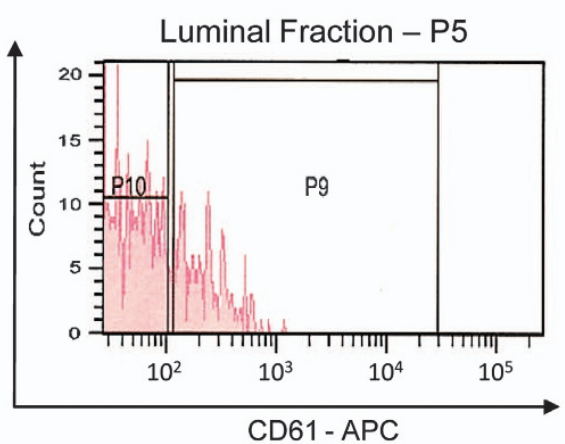

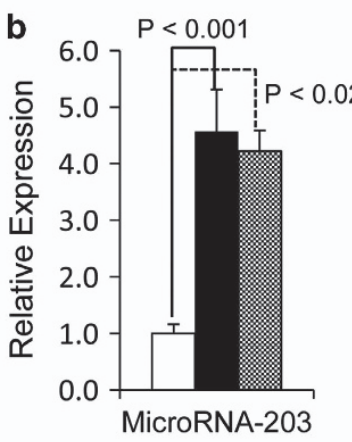

d
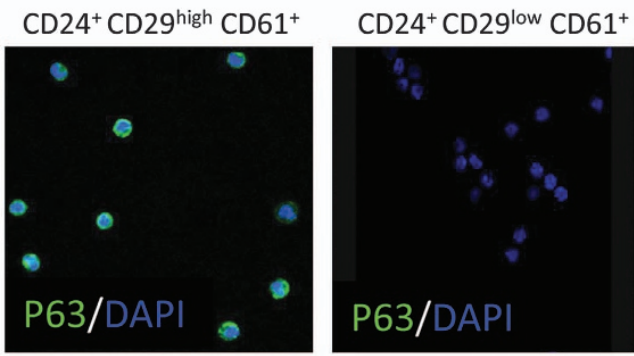

\section{f}

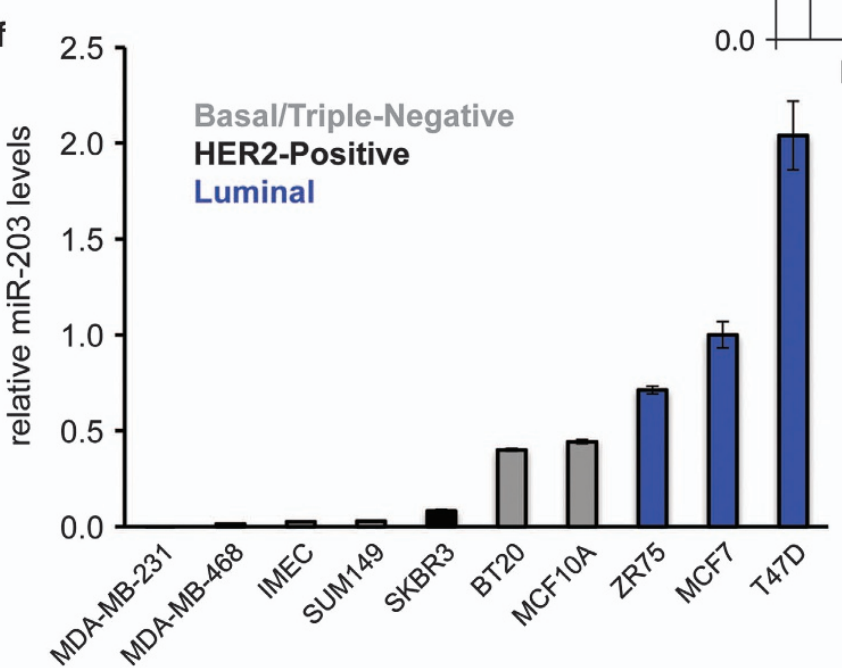

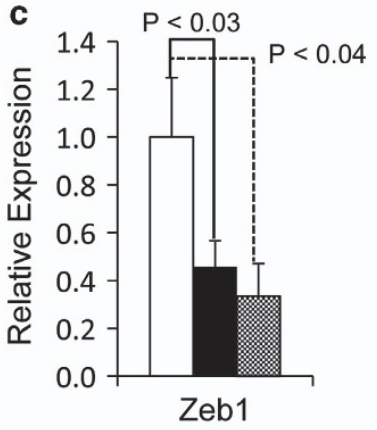

e

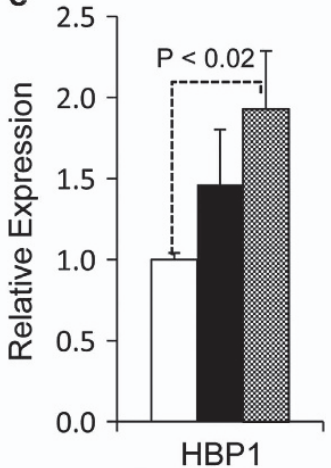

HBP1

\section{Mammary}

Stem cell

CD24 ${ }^{+}$CD29 ${ }^{\text {high }} \mathrm{CD} 1^{+}$

Luminal

Progenitor

$\mathrm{CD} 24^{+} \mathrm{CD} 29^{\text {low }} \mathrm{CD} 1^{+}$

Differentiated

Luminal cell

CD24+CD29 ${ }^{\text {low }}$ CD61

Figure 1 Expression of miR203 correlates with differentiation in the mammary epithelium. (a) Fluorescence-activated cell sorting (FACS) of negative lineage selected mammary epithelial cells excised from the mouse mammary gland and labeled with CD29, CD24 and CD61. Labeled mammary epithelial cells were gated for isolation of MaSCs, luminal progenitor and differentiated luminal cell fractions based on CD29, CD24 and CD61 status. (b) qRT-PCR analysis of isolated mammary cells fractions for detection of mature miR203 expression. (c) Total RNA was isolated from mammary cell fractions for qRT-PCR analysis on ZEB mRNA expression. (d) Immunofluorescent staining against P63 from mammary epithelial stem cells (left) and luminal mammary cells (right) applied to glass microscope slides. (e) qRT-PCR analysis of isolated mammary cell fractions for detection of HBP1 mRNA (transcriptionally repressed by $\triangle N P 63 \alpha$ ). (f) Mature miR-203 expression levels normalized to SnU6 from RNA lysates of 10 mammary and breast cancer cell lines using two-step TaqMan assays. All data are means \pm S.E.; $n=2, P$-values are indicated 
(DIP). ${ }^{41}$ These cultures undergo lactogenic differentiation and express high levels of $\beta$-casein in response to EGF withdrawal and treatment with DIP (Figure 2e). Analysis of cells treated with vehicle or DIP for $72 \mathrm{~h}$ revealed that DIP caused decreased expression of Zeb1 (Figure 2a), increased expression of miR203 (Figure $2 \mathrm{~b}$ ), suppression of $\Delta \mathrm{Np} 63 \alpha$ protein (Figure 2c), while $\Delta \mathrm{Np} 63 \alpha$ mRNA remained unchanged (Supplementary Figure S2), and increased expression of HBP1 (Figure 2d). These results are consistent with the patterns of gene expression observed in the murine mammary epithelial hierarchy (Figure 1). They also suggest that the induction of HBP1 and $\beta$-casein may require suppression of $\Delta \mathrm{Np} 63 \alpha$. To test this, $\Delta \mathrm{Np} 63 \alpha$ was expressed with a heterologous $3^{\prime}$ UTR that is insensitive to miR203 in HC11 cells and treated with vehicle or DIP. QRT-PCR-based analysis indicated that the DIP-dependent induction of HBP1 was disrupted by ectopic $\Delta \mathrm{Np} 63 \alpha$ (Figure 2f). This result is consistent with previous studies indicating that HBP1 is directly repressed by $\Delta \mathrm{Np} 63 \alpha{ }^{35}$ Similarly, DIP-dependent luminal epithelial differentiation, as measured by induction of $\beta$-casein, was disrupted by ectopic $\Delta N p 63 \alpha$ indicating that suppression of $\Delta \mathrm{Np} 63 \alpha$ is required for DIP-induced luminal differentiation (Figure $2 \mathrm{~g}$ ). Together, these results support a model in which induction of miR203 and suppression of $\Delta \mathrm{Np} 63 \alpha$ expression are required for luminal epithelial differentiation in the DIP-induced $\mathrm{HC} 11$ model system (Figure 2h).

\section{MiR203 induces G0/G1 arrest and blocks colony forma-} tion capacity that is rescued by $\Delta \mathrm{Np} 63 \alpha$. To determine if induction of miR203 associated with mammary epithelial differentiation mediates repression of $\Delta \mathrm{Np} 63 \alpha$ and forfeiture of self-renewal; miR203 was transfected into two immortalized mammary epithelial cells (IMECs), IMEC and HC11, both of which have features of MaSCs including high levels of $\Delta \mathrm{Np} 63 \alpha$. Western analysis of transfectants revealed that miR203 significantly reduced expression of $\Delta N p 63 \alpha$ in IMECs and HC11 cells (Figure 3a). In these studies, it was also noted that transfection of miR203 but not miR-CON (control) resulted in a substantial reduction in cell number in the $\mathrm{HC} 11$ cultures within $48 \mathrm{~h}$ of transfection (Figure $3 \mathrm{~b}$ ). Similar, but less dramatic results were observed in IMECs (data not shown), which is likely due to the slower proliferation rates of IMECs. This observation coupled to studies indicating that $\Delta \mathrm{Np} 63 \alpha$ is required for retention of proliferative potential, ${ }^{11}$ suggested that the reduction in cell number within miR203 transfectants may be the result of a proliferative arrest. To test this, $\mathrm{HC} 11$ cells were transfected with miR-CON or miR203 and cell cycle distribution was analyzed by propidium iodine staining at $72 \mathrm{~h}$ after transfection. Results indicated a substantial accumulation of cells in the $2 \mathrm{~N}$ state (Figure $3 \mathrm{c}$ ), suggesting that cells had either undergone proliferative arrest or had become quiescent. This result suggests that miR203 has a potent anti-proliferative effect, which is consistent with the observed increase in miR203 expression during cellular differentiation. To determine if the anti-proliferative effects of miR203 required suppression of $\Delta \mathrm{Np} 63 \alpha$, IMEC cells were infected with retroviruses programmed to express nothing (pLPC) or the open reading frame of $\Delta \mathrm{Np} 63 \alpha$ (pLPC- $\Delta$ Np63 $\alpha^{\mathrm{ORF}}$ ), which renders it resistant to miR203-mediated repression, and then transfected with miR-CON or miR203. Results indicated that ectopic miR203 prevented colony formation (Figure 3d). Importantly, the anti-clonogenic effect of miR203 was potently rescued by expression of $\Delta \mathrm{Np} 63 \alpha$, indicating that miR203 is able to suppress $\Delta \mathrm{Np} 63 \alpha$ in a manner that is consistent with forfeiture of proliferative capacity in mammary epithelium.

MiR203 opposes the activities of normal and cancer stem cells. The ability of miR203 to repress $\Delta \mathrm{Np} 63 \alpha$ expression (Figure $3 a$ ) and disrupt $\Delta$ Np63 $\alpha$-mediated clonogenicity (Figure $3 d$ ) suggests a role in the forfeiture of stem cell properties. A common feature of epithelial stem cells is the ability to form multicellular structures that can proliferate in an attachment-independent manner. These structures, referred to as mammospheres, are derived from MaSCs and this culture system has been used to enrich for tumorigenicity within breast tumors and breast cancer cell lines. ${ }^{42}$ The ability to enrich for subpopulations with stem cell features coupled to the observed increase in miR203 levels in nonstem populations (Figures 1 and 2) suggested that miR203 levels would be reduced in mammospheres relative to their parental monolayer culture. To test this, miR203 levels were measured in MCF7 cells derived from monolayer and mammosphere cultures. Results indicated miR203 levels are reduced in the mammospheres (Figure 4a). To determine the effects of miR203 on mammosphere forming capacity, IMEC cells were either mock transfected or transfected with miR-CON or MiR203 and 25000 cells from each transfection were cultured under low attachment conditions for 14 days. Visual inspection of the cultures indicated that ectopic miR203 completely ablated mammosphere formation (Figure $4 \mathrm{~b}$ ) and this was quantified by counting cells following gentle trypsinization of the mammospheres (Figure 4b). These data suggest that miR203 is sufficient to disrupt mammosphere forming capacity, which is consistent with a model in which miR203 subverts the stem cell phenotype. Several studies have demonstrated a substantial enrichment of stem cells within the CD44 ${ }^{+} / \mathrm{CD} 24^{-}$fraction of breast tumors and breast cancer cell lines. ${ }^{43,44}$ To determine the effects of miR203 on this feature of stem cells, IMEC cells were mock transfected or transfected with miR-CON or miR203 and $\mathrm{CD}_{4}{ }^{+} / \mathrm{CD}_{2} 4^{-}$fractions were quantified by flow cytometry. IMECs were chosen for this study because of their high proportion of $\mathrm{CD} 44^{+} / \mathrm{CD} 24^{-}$cells and their low endogenous levels of miR203. Results indicated that ectopic miR203 caused a reduction in the $\mathrm{CD} 44^{+} / \mathrm{CD} 24^{-}$population from 97.5 to $79.3 \%$ relative to the miR-CON transfectants (Figure 4c). This reduction was due in large part to an increase in $\mathrm{CD}_{4} 4^{+} / \mathrm{CD} 24^{+}$cells suggesting that miR203 caused an increase in the number of cells that had forfeited self-renewing capacity. Together, these data indicate that miR203 is sufficient to subvert the phenotypic properties of MaSCs.

MiR203 is negatively regulated by Zeb1 and is inversely expressed in mammary and breast cancer cell lines. The previous data (Figures 1 and 2) coupled to a recent study indicating that Zeb1 promotes a stem cell phenotype via 

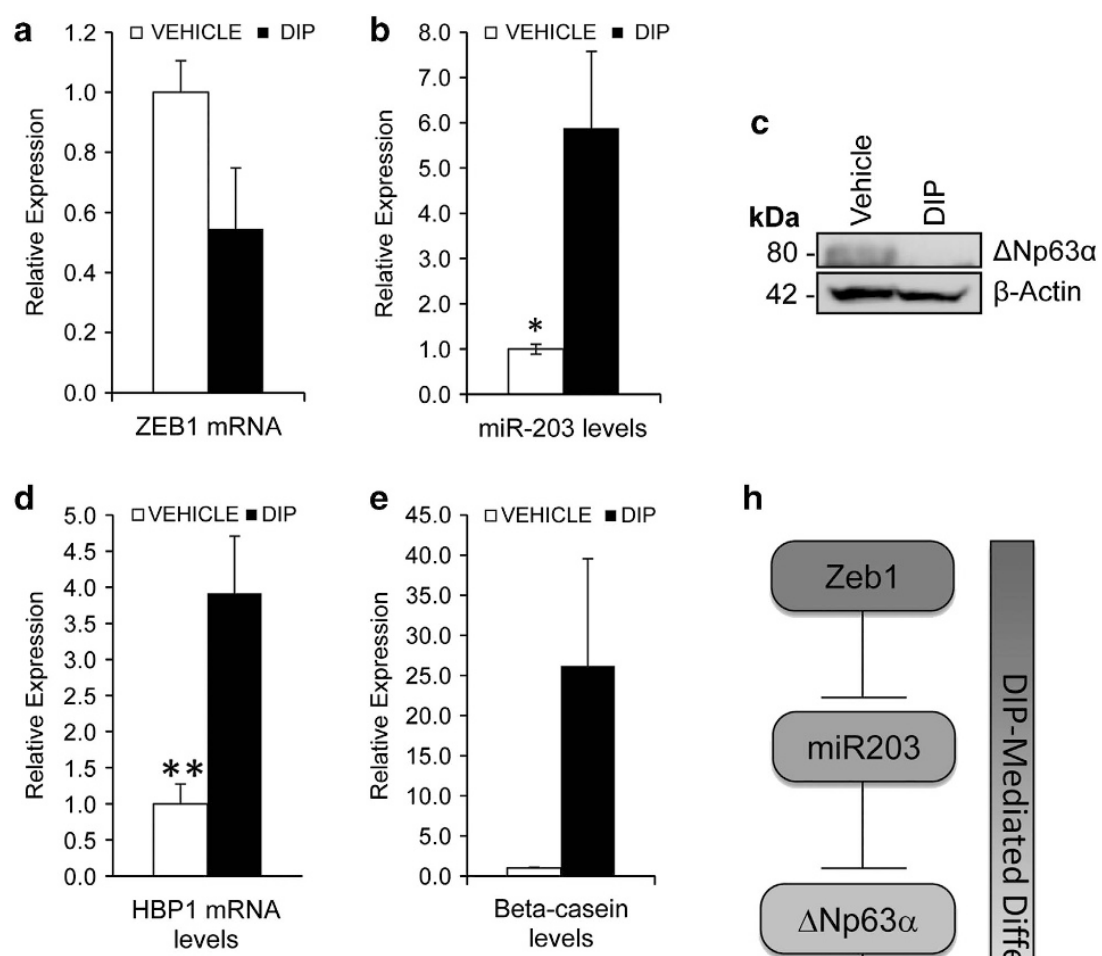

h
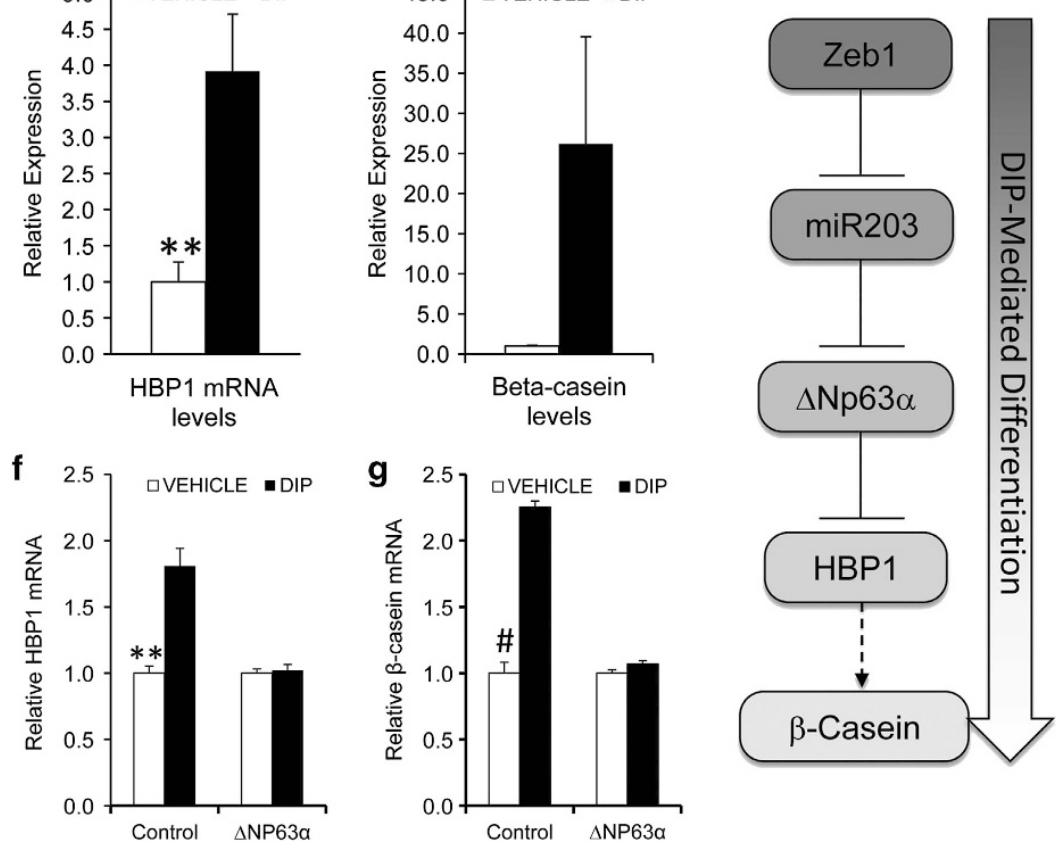

Figure 2 Modulation of the ZEB1-miR203- $\triangle$ NP63 $\alpha$ pathway during luminal epithelial differentiation. The mouse mammary epithelial cell line HC11was plated and on confluence were then withdrawn of EGF for $48 \mathrm{~h}$. Cells were then treated with differentiation inducing media (DIP) for $72 \mathrm{~h}$. Cells were collected for RNA and protein analysis. Total RNA was isolated from cells for qRT-PCR analysis to detect (a) ZEB1 mRNA, (b) mature miR203, (d) HBP1 mRNA and (e) $\beta$-casein mRNA. (c) Western blot analysis was performed on $\mathrm{HC11}$ protein lysates to detect $\triangle \mathrm{NP} 63 \alpha$ protein expression levels. (f and $\mathbf{g}$ ) $\mathrm{HC} 11$ cells were treated with DIP differentiating media for $72 \mathrm{~h}$ in the presence or absence of an adenovirus expressing the ORF of $\triangle N P 63 \alpha$ (lacking the UTR's), which cause resistance to miR-203 translational inhibition. qRT-PCR analysis were performed on total RNA lysates to detect mRNA expression levels of HBP1 (f), and $\beta$-casein (g). Data are means \pm S.D.; $n=3,{ }^{*} P<0.00004,{ }^{* *} P<0.02$ and ${ }^{\#} P<0.005$. (h) Schematic of the regulatory pathway that mediates the downregulation of $\triangle \mathrm{NP} 63 \alpha$ protein during luminal mammary cell differentiation

transcriptional repression of miRNAs suggest that transcriptional repression of miR203 by Zeb1 promotes $\Delta$ Np63 $\alpha$ expression. ${ }^{38}$ To test this prediction and determine its relevance to breast cancer, a panel of immortal and transformed mammary epithelial cell lines representing poorly differentiated to well differentiated states was evaluated for Zeb1 mRNA levels and miR203 levels. Results indicate that Zeb1 expression is highest in poorly differentiated cells and miR203 expression is highest in welldifferentiated cells (Figure 5a). This inverse correlation suggests that Zeb1 promotes expression of $\Delta \mathrm{Np} 63 \alpha$ via repression of miR203. Si-RNA-mediated suppression of Zeb1 resulted in a robust increase in miR203 levels (Figure $5 \mathrm{~b}$ ) and sharply lowered levels of $\Delta \mathrm{Np} 63 \alpha$ protein (Figure 5c). Conversely, gain-of-function studies in MCF10A cells, which were chosen for their low levels of Zeb1, indicated that ectopic Zeb1 repressed expression of miR203 (Figure 5d) and increased $\Delta N p 63 \alpha$ levels (Figure 5e). Together, these studies support a model in which Zeb1-mediated suppression of miR203 enhances expression of $\Delta \mathrm{Np} 63 \alpha$.

MiR203 promotes MET. The observation that Zeb1 actively represses miR203 coupled to its role in promoting EMT suggests that miR203 may be differentially expressed during this transition. To test this, $\operatorname{CD} \beta$-Geo cells, a derivative of $\mathrm{HC} 11$ cells, were treated with $\operatorname{TGF} \beta$ to induce EMT. ${ }^{45}$ Immunofluorescent analysis of these cells indicated that $\operatorname{TGF} \beta$ treatment resulted in a sharp decrease in E-cadherin expression, a hallmark feature of EMT (Figure 6a). Post-EMT 


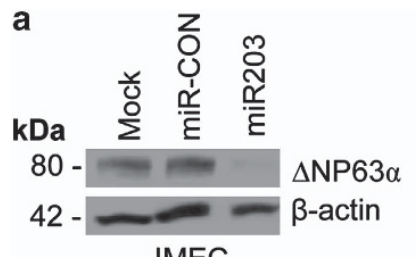

IMEC

b

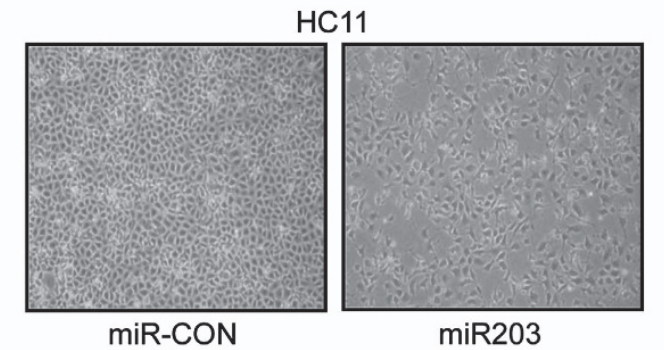

c

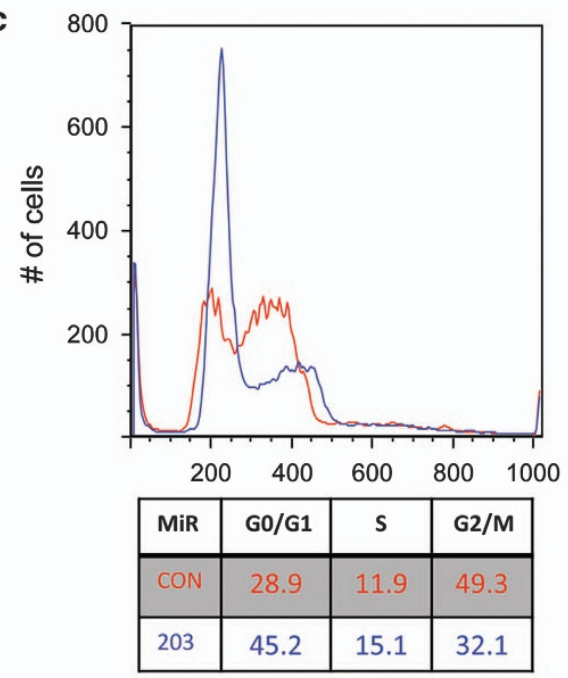

d

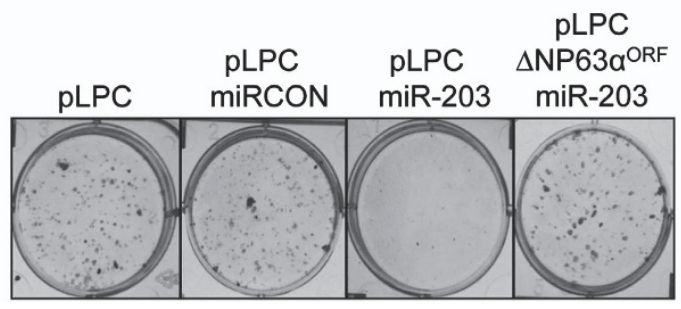

Figure 3 MiR203 induces G0/G1 arrest and blocks colony formation capacity in a manner that is rescued by $\triangle N P 63 \alpha$. (a) Western blot analysis of protein lysates from IMEC (left) and $\mathrm{HC11}$ (right) cells transiently transfected with mature miR203 $(60 \mathrm{~nm})$ for $48 \mathrm{~h}$ and probed with an anti-P63 antibody (4A4). (b) $10 \times$ Phase contrast microscopy of $\mathrm{HC} 11$ cells transiently transfected with mature miR203 $(60 \mathrm{~nm})$ for $72 \mathrm{~h}$. (c) PI cell cycle analysis was performed via flow cytometry of $\mathrm{HC} 11$ cells transiently transfected with mature miR203 for $72 \mathrm{~h}$ (cells were treated with nocodizole to synchronize cells before PI cell cycle analysis). (d) IMEC cells were either infected with an empty retrovirus or a retrovirus expressing the open reading frame of $\triangle N P 63 \alpha$ (pLPC$\triangle \mathrm{NP} 63 \alpha^{\mathrm{ORF}}$ ) and then transiently transfected with either a miR-control or mature miR203 $(60 \mathrm{~nm})$ and then plated for colony formation assay. Colonies were stained with crystal violet and imaged. All experiments were performed in triplicate $(n=3)$

cells expressed significantly less miR203 compared with untreated $\mathrm{CD} \beta$-Geo cells (Figure $6 \mathrm{~b}$ ). Conversely, Zeb1 mRNA expression was increased in post-EMT $\operatorname{CD} \beta$-Geo cells, which suggest that it may be a contributing factor to the reduction of miR203 expression (Figure 6b). This observation suggests that suppression of miR203 levels is required for EMT and that miR203 may oppose EMT. Consistent with this prediction, transfection of miR203 into IMECs resulted in a sharp induction of E-cadherin and a corresponding decrease in vimentin demonstrating that miR203 opposes EMT and promotes MET (Figure 6c). These results propose that miR203 may restrict cell motility, a hallmark of EMT. To test this, MDA-MB-231 cells, which display features of EMT including enhanced cell motility, were cultured to confluence and mock transfected, or transfected with miR-CON or miR203. At $24 \mathrm{~h}$ after transfection, uniform scratches were etched onto the monolayer and cells were visually monitored over $48 \mathrm{~h}$ to observe the rates at which cells re-colonize the scratch. Digital imaging (Figure 6d) and quantification (Figure $6 \mathrm{e}$ ) indicated that transfection of miR203 potently inhibited the ability of cells to recolonize the scratch, suggesting that miR203 restricts cell motility. Together, these data indicate that expression of miR203 is reduced in cells that have undergone EMT and that miR203 is sufficient to promote MET and reduce cell motility.

\section{Discussion}

Data presented here support a model in which induced expression of miR203 is an early event in the mammary epithelial hierarchy that mediates forfeiture of self-renewing capacity by suppressing $\Delta N p 63 \alpha$. Our data indicate that miR203 correlates with differentiation in breast cancer cell lines and in the mammary epithelial hierarchy. In addition, miR203 expression increases in response to induction of differentiation and that differentiation depends on suppression of $\Delta \mathrm{Np63 \alpha}$. Importantly, ectopic expression of miR203 in HC11 and IMEC cells was not sufficient to induce differentiation as indicated by $\beta$-casein expression (data not shown), however, it did suppress $\Delta \mathrm{Np} 63 \alpha$, which lead to induction of the pro-differentiation gene HBP1 (Supplementary Figures $3 \mathrm{~A}$ and B). These data are consistent with miR203 functioning early in the differentiation pathway to mediate the forfeiture of self-renewing capacity. In addition, gain-of-function studies indicate that miR203 is anti-proliferative, disrupts self-renewal and is potently anti-clonogenic. This latter feature is rescued by ectopic $\Delta N p 63 \alpha$, indicating that this effect is mediated via suppression of $\Delta N p 63 \alpha$. Suppression of miR203 correlates with expression of Zeb1, which is a negative prognostic factor in breast cancer. These findings suggest a mechanism by which Zeb1 contributes to poor prognosis and suggests that miR203 may function as a tumor suppressor that promotes an orderly progression through the mammary epithelial hierarchy. Additional studies will be necessary to determine if miR203 has tumor-suppressor activity.

We have described a regulatory pathway that is differentially activated during cellular differentiation (Figure 2 and Supplementary Figure 3C). In the undifferentiated stem and progenitor cells, expression of Zeb1 suppressed miR203 expression thereby increasing $\Delta \mathrm{Np} 63 \alpha$ protein and suppressing expression of HBP1 (Figures 1 and 2). Conversely, in a differentiated state, Zeb1 expression is repressed resulting in increased miR203 levels, suppression of $\Delta \mathrm{Np} 63 \alpha$ and 
a

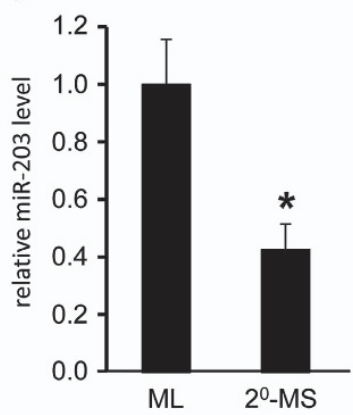

b

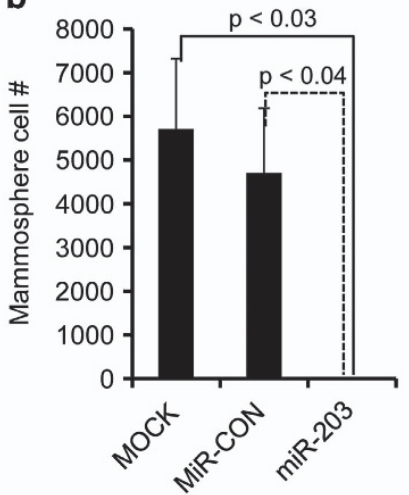

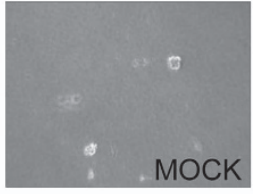
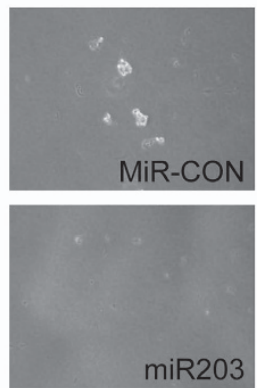

c Unlabeled-Ctrl

Labeled-Ctrl
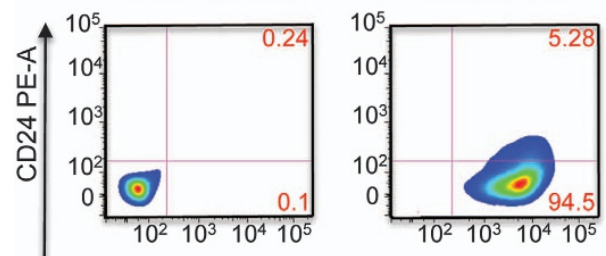

miR-Con

miR-203
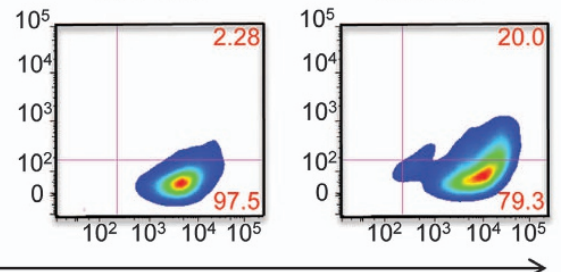

CD44 FITC-A

Figure 4 MiR203 opposes the activities of normal and cancer stem cells. (a) RT-qPCR analysis of total RNA for mature miR-203 expression levels isolated from parental (ML) and secondary mammospheres ( $2^{\circ}-\mathrm{MS}$ ) of MCF-7 cells (mammospheres enrich for stem cells). Data are means \pm S.D.; $n=3$, asterisk indicates $P<0.05$. (b) Mammosphere formation assay of IMEC cells transiently transfected with miR-control of mature miR203 $(60 \mathrm{nM}) ; 25000$ cells were then transferred to low binding plates and grown for 14 days. Mammospheres were trypsinized and total cells were counted per experimental group (left), Representative $10 \times$ phase contrast images of mammospheres from each experimental group (right). Data are means \pm S.E.; $n=3, P$-values are indicated. (c) Flow cytometric analysis of IMECs labeled with the stem cell enrichment markers CD24 and CD44. IMECs were transiently transfected with miR-control or mature miR203 (60 nM). Seventy-two hours after transfection, cells were labeled with CD24-PE and CD44-FITC and analyzed via flow cytometry. Representative flow cytometry density plots of CD24 versus CD44 from experiment conduced in triplicate

increased expression of HBP1 (Figure 2). HBP1 has been previously identified as a tumor suppressor in breast cancer, ${ }^{46}$ a target of transcriptional repression of $\Delta \mathrm{Np} 63 \alpha^{39}$ and a mediator of differentiation. ${ }^{47}$ It is also a potent inhibitor of Wnt signaling, which maintains self-renewal, suggesting that induction of HBP1 downstream of miR203 may contribute to the forfeiture of self-renewal. ${ }^{46,48}$ In addition, in the $\mathrm{HC} 11$ model of luminal differentiation, $\mathrm{HC} 11$ cells are grown in the undifferentiated state via EGF treatment. Following EGF withdrawal, $\mathrm{HC} 11$ cells are induced to a committed predifferentiated progenitor state, which are then committed to a complete differentiated state by addition of DIP. We observed initial induction of miR203 as early as the pre-differentiated state on EGF withdrawal (data not shown); which supports miR203 as an early mediator in the differentiation pathway, most likely to facilitate the forfeiture of stem cell properties. Furthermore, in a recent study, miRNA targeted gene profiling identified overlapping signatures between the undifferentiated stem cell-like HC11 state and poor prognosis where patients exhibiting a SC-like miRNA profile had lower survival rates. ${ }^{49}$ It will therefore be of interest to determine if expression of miR203 correlates with a favorable prognosis in breast cancer patients. In addition, as miR203 targets $\Delta$ Np63 $\alpha$ and BMI1, another protein implicated in the preservation and activity of stem cells, it will be of interest to determine if miR203 expression can identify patients at low risk for breast cancer recurrence.

We present evidence that ablation of Zeb1 leads to increased expression of miR203 and suppression of $\Delta \mathrm{Np} 63 \alpha$. Coupled to several studies implicating Zeb1 in activation of pro-EMT transcriptional programs, ${ }^{38,50}$ and tumor cell dedifferentiation, ${ }^{29}$ our study implicates miR203 in the specification of epithelial cell fate. Further, it suggests that miR203 mediates forfeiture of cellular plasticity, which is a hallmark of EMT and cancer stem cell behavior. ${ }^{51}$ In addition, ZEB1 is overexpressed in various cancer cell lines, including breast, and has been shown to promote tumor cell migration and metastasis. ${ }^{52}$ Similarly, a miRNA expression profiling study of human metastatic cancers and paired primary tumors found miR203 to be consistently underexpressed in the metastatic tissue, ${ }^{53}$ further implicating a relationship between ZEB1 regulation of miR203 and tumor invasiveness and metastasis. Coupled with data presented in this study, miR203 appears to have an anti-tumorigenic role, and its expression may coincide with metastatic potential.

Finally, we show that miR203 was sufficient to induce a MET and a decrease in the breast cancer stem cell population (Figures 5 and 6). Of interest, ectopic miR203 significantly increased the expression of the luminal cell surface marker CD24, further implicating miR203 as a mediator of luminal cell 


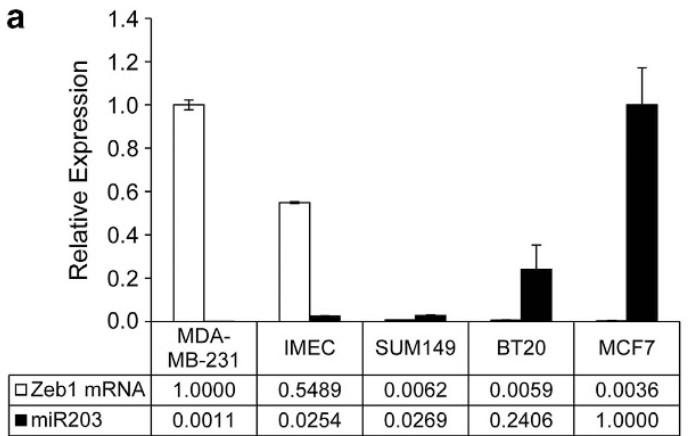

b

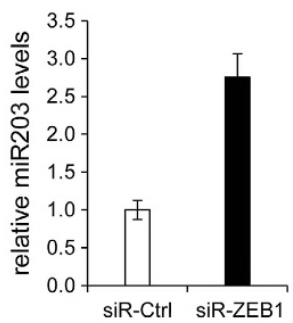

C

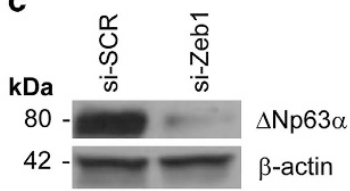

d

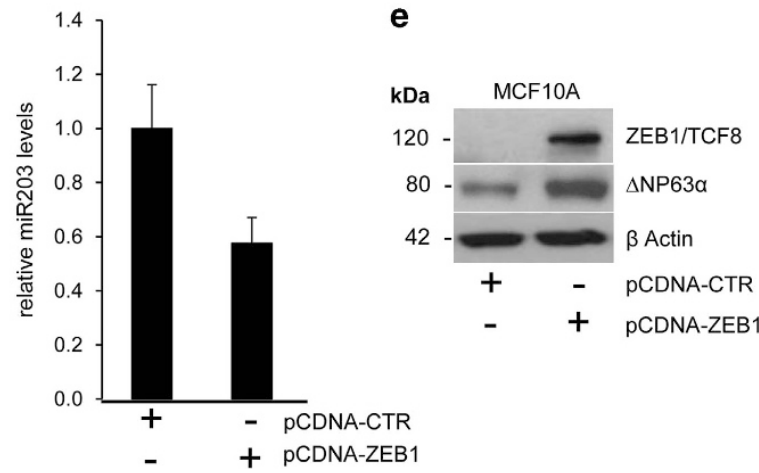

Figure 5 MiR203 is negatively regulated by ZEB1 and is inversely expressed in mammary and breast cancer cell lines. (a) Total RNA was isolated from five mammary and breast cancer cell lines and qRT-PCR analysis to detect ZEB1 mRNA and mature miR203 was performed. (b and $\mathbf{c}$ ) IMEC cells were transiently transfected with siRNA against ZEB1 or scramble control $(60 \mathrm{~nm})$ and harvested $48 \mathrm{~h}$ later for qRT-PCR analysis on mature miR203 (b) and western blot analysis using an anti-P63 antibody (c). (d and e) MCF10A cells were transiently transfected with an empty mammalian expression plasmid ( $\mathrm{PCDNA}-\mathrm{CTR}$ ) or one encoding murine Zeb1 (pCDNA-Zeb1). Cells were collected $72 \mathrm{~h}$ after transfection and analyzed using qRT-PCR for mature miR203 detection and western blot using antiZeb1 and anti-P63 antibodies. Data are means \pm S.D.; $n=3$

fate and commitment. It is possible that miR203 suppression is a mechanism by which cancer cells can acquire an EMT, stem cell-like phenotype in order to garner an aggressive, prometastatic phenotype. Taken together, we have described miR203 as a potent inhibitor of stem cell function through the targeted inhibition of $\Delta \mathrm{Np} 63 \alpha$, which may have a role in breast cancer development.

\section{Materials and Methods}

Cell culture. A total of 10 mammary epithelial or breast cancer cell lines (MDAMB-231, MDA-MB-468, SUM149, SKBR3, BT20, MCF10A, HCC1937, ZR75, T47D and MCF7) were examined in this study. Each was maintained according to ATCC guidelines. Establishment and maintenance of the IMEC line has been previously described. ${ }^{7,54}$
Western blot analysis. Total cell protein extracts were obtained using NETN lysis buffer (100 mM Tris-Cl (pH 7.8), $1 \mathrm{mM}$ EDTA, $100 \mathrm{mM} \mathrm{NaCl}$, and $0.1 \%$ Triton X-100) supplemented with protease and phosphatase inhibitors (Roche, Branchburg, NJ, USA). Protein concentrations were measured by Lowry protein assay and $10 \mu \mathrm{g}$ of protein per sample was resolved on an $8 \%$ SDSpolyacrylamide gel and transferred onto a PVDF membrane. Membranes were blocked with TBST $5 \%$ non-fat dry milk for $1 \mathrm{~h}$ at room temperature, incubated with primary antibodies overnight at $4{ }^{\circ} \mathrm{C}$, washed and incubated for $1 \mathrm{~h}$ at room temperature with horseradish peroxidase-conjugated secondary antibody.

Antibodies. For western blotting, mouse anti-p63 (4A4) (LabVision, Kalamazoo, MI, USA; $1 / 500$ dilution), mouse anti- $\beta$-actin (Cell Signaling, Boston, MA, USA; 1/1000 dilution) antibodies were used. For sorting primary mammary epithelial cells from mice, antibodies against mouse antigens include CD24-PE (BD Biosciences, San Jose, CA, USA; 1/100 dilution), CD29-FITC (BD Biosciences; 1/100 dilution), and CD61-APC (Invitrogen, Grand Island, NY, USA; 1/100 dilution). Secondary antibodies used were anti-mouse IgG (Sigma, St. Louis, MO, USA; 1/10000 dilution). For flow cytometry experiments, FITCconjugated mouse anti-human CD44 and PE-conjugated mouse anti-human CD24 (BD Biosciences) were used.

RT-qPCR. RNA was isolated using RNeasy mini kit or miRNeasy mini kit for mRNA and miRNA, respectively (Qiagen, Valencia, CA, USA) as per the manufacturer's protocol. For mRNA analysis, RNA $(1 \mu \mathrm{g})$ was reverse transcribed using random hexamers and Q-PCR was conducted using the SsoFast Eva Green master mix (Bio-Rad, Hercules, CA, USA). The $2^{-\Delta \Delta C T}$ method was used for quantification of gene expression changes. Relative changes were normalized to glyceraldehyde-3-phosphate dyhydrogenase or $\beta$-actin for differentiation experiments. The relative expression levels of miR203 were measured using a two-step Taqman assay according to the manufacturer's protocol. RNA $(10 \mathrm{ng})$ for miRNA analysis was reverse transcribed using Taqman Reverse Transcriptase Kit (Applied Biosystems, Carlsbad, CA, USA) for miR203 or the internal control SnU6. Taqman real-time PCR was prepared using Universal PCR Master Mix No AmpErase UNG (Applied Biosystems) and specific primers for miR203 and SnU6 from Taqman MicroRNA Assays (Applied Biosystems). Expression levels of miR203 were based on the amount of the target message relative to that of the SnU6 transcript as a control to normalize the initial input of total RNA.

MiRNA analysis and transfections. For miRNA overexpression, $2.5 \times 10^{5}$ cells per well were seeded in six-well-plates. Pre-miR (Applied Biosystems) mimicking mature miR203 or control nonspecific miRNA (Pre-miRnegative control NC\#1; Applied Biosystems) was transfected at $60 \mathrm{nM}$ final concentration into cells using Oligofectamine transfection reagent (Invitrogen). At $24 \mathrm{~h}$ after transfection, cells were assessed for $\Delta \mathrm{Np} 63 \alpha$ protein content via western blot. For cell cycle analysis of $\mathrm{HC} 11$ cells transfected with Pre-miR203 or control, cells were split $1: 4,48 \mathrm{~h}$ after transfection and subsequently collected for propidium iodide (PI) staining $72 \mathrm{~h}$ after transfection. For experiments involving ZEB1 knockdown, IMEC cells were transfected with either scramble si-control or a siRNA targeted against ZEB1 at $60 \mathrm{nM}$ final concentration using Oligofectamine Transfection Reagent (Invitrogen). For ZEB1 overexpression experiments, MCF10A cells were transfected with an empty control mammalian expression plasmid (pCDNA-CTR) or one encoding murine ZEB1 (pCDNA-ZEB1) using Lipofectamine 2000 Transfection reagent (Invitrogen). Cells were harvested 48 and $72 \mathrm{~h}$ after transfection for analysis.

Lactogenic differentiation of HC11 cells. The prolactin-responsive cell line, HC11, was split 1:5 and maintained in RPMI 1640 medium containing 10\% fetal bovine serum, L-glutamine, $5 \mu \mathrm{g} / \mathrm{ml}$ insulin and $10 \mathrm{ng} / \mathrm{ml}$ epidermal growth factor. For induction of differentiation the cells were grown to confluence and then kept in the above media without EGF for $48 \mathrm{~h}$ to induce competence. Differentiation-competent cells were incubated in RPMI 1640 medium containing $10 \%$ fetal bovine serum, L-glutamine, $5 \mu \mathrm{g} / \mathrm{ml}$ insulin and supplemented with $100 \mathrm{nM}$ dexamethasone, $5 \mu \mathrm{g} / \mathrm{ml}$ insulin, in the presence or absence of $5 \mu \mathrm{g} / \mathrm{ml}$ prolactin for $72 \mathrm{~h}$.

Cell cycle distribution analysis. Cells were collected at approximately $60 \%$ confluence and fixed in $70 \%$ ethanol for $48 \mathrm{~h}$ at $-20{ }^{\circ} \mathrm{C}$. Cells were washed in PBS supplemented with $3 \%$ FBS and resuspended in buffer (PBS, 0.1\% Triton $\mathrm{X}-100$, DNase-free RNAse-A $100 \mu \mathrm{g} \mathrm{ml}^{-1}$ ) with $50 \mu \mathrm{g} \mathrm{ml}^{-1}$ of PI. Following 
a

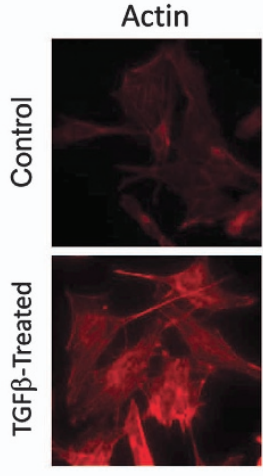

C

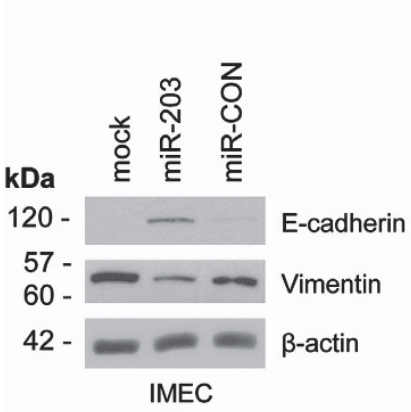

E-cadherin
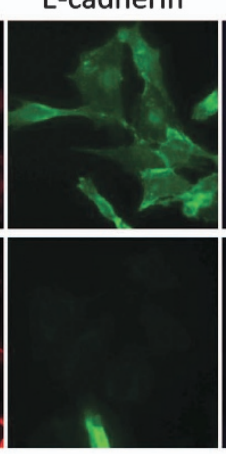

d
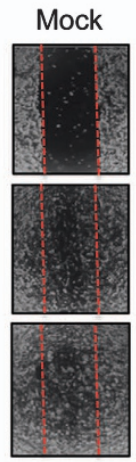

DAPI
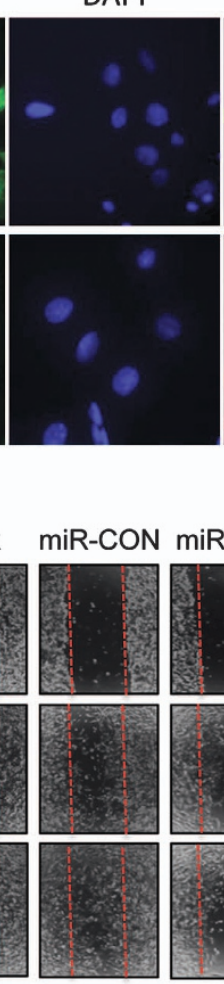

Merge
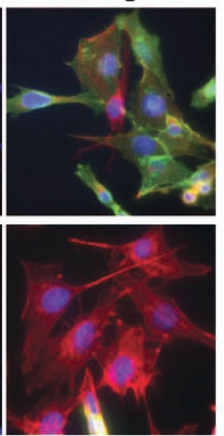

b
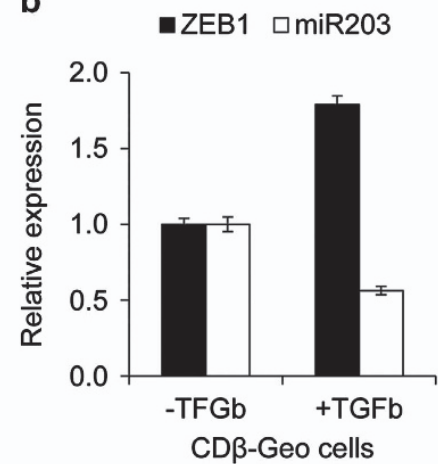

e

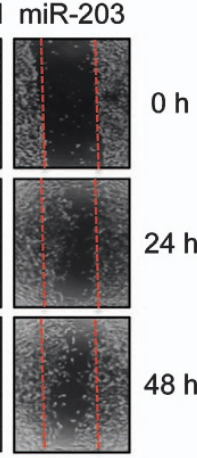

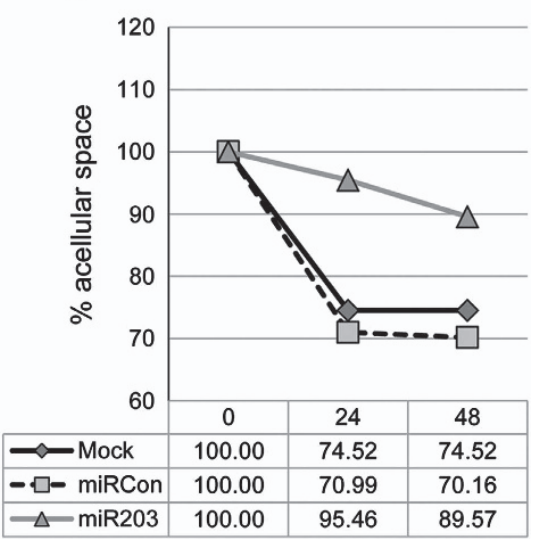

Figure 6 MiR203 promotes MET. (a) Immunofluorescent images stained for E-cadherin (green), $\beta$-actin (red) and DAPI for nuclear localization of CD $\beta$-Geo cells that have been treated with vehicle (control) or TGFb. (b) Total RNA was isolated from CD $\beta$-Geo cells that have not $(-)$ or have undergone EMT $(+)$ and qRT-PCR analysis was performed to measure Zeb1 mRNA and mature miR203 expression levels. (c) Western blots of protein lysates from IMEC cells transiently transfected with miR-control or mature miR203 $(60 \mathrm{~nm})$ for $48 \mathrm{~h}$ were probed with anti-E-cadherin and anti-vimentin antibodies. (d) MDA-MB-231 cells were transiently transfected with miR-control or mature miR203 $(60 \mathrm{~nm})$ and plated for wound healing assay. At $90 \%$ confluence the cells were scratched and then observed for $48 \mathrm{~h}$ to measure closure of the wound. $10 \times$ phase contrast microscopy of wound healing assay at 0,24 and $48 \mathrm{~h}$ after scratch (c) and quantification of re-migration of the cleared space between experimental controls (e). All experiments were performed in triplicate $(n=3)$ and data are means \pm S.D.

incubation at $37^{\circ} \mathrm{C}$ for $1 \mathrm{~h}, \mathrm{PI}$ fluorescence distribution of 20000 single cells was measured with a FACScan Flow Cytometer (BD Biosciences). Subsequent data were analyzed with FlowJo cell cycle software (Ashland, OR, USA).

Mammosphere formation. Human IMECs were transfected with $60 \mathrm{nM}$ final concentration of miR203, miR-control or mock control. At $24 \mathrm{~h}$ after transfection, cells were trypsinized and seeded at 25000 cells per $10 \mathrm{~cm}$ plate coated with poly-2-hydroxyethyl methacrylate $(20 \mathrm{mg} / \mathrm{ml})$. Cells were grown in low binding conditions for 14 days and collected for analysis.

Retroviral infection and colony formation assay. Platinum- $A$ retroviral packaging cell line (Cell BioLabs Inc., San Diego, CA, USA) was transfected with the mammalian retroviral expression vector pLPC (Addgene, Cambridge, MA, USA) containing the open reading frame of $\triangle \mathrm{NP} 63 \alpha^{\mathrm{ORF}}$, or empty vector control (pLPC). At $24 \mathrm{~h}$ after transfection, viral titers were collected and used to infect IMECs. Seventy-two hours after infection; IMECs were transfected with miR203 or nonspecific miR-control. At $24 \mathrm{~h}$ after transfection, cells were plated at colony formation density (1000 cells per well in a six-well tissue culture plate). Colonies were stained using crystal violet 12 days after plating cells.

Mammary cell preparation and FACS cell sorting. Dissection and single cell suspension of the thoracic and inguinal mammary glands from virgin female mice were prepared as previously described. ${ }^{9}$ Negative lineage selection was performed on the RoboSep fully automated cell separator (StemCell Technologies, Vancouver, BC, Canada) using the mouse Easy-Sep MaSC enrichment kit (StemCell Technologies). Cells were subsequently labeled with antibodies against mouse antigens and include CD24-PE, CD29-FITC and CD61APC. FACS analysis and cell sorting were performed using a FACS Aria (BD Biosciences).

Flow cytometry analysis. Cells were trypsinized and washed once with PBS containing 2\% FBS (wash buffer), and resuspended in $50 \mu \mathrm{l}$ of wash buffer. Fluorochrome-conjugated monoclonal antibodies against human CD44-FITC and CD24-PE or their respective controls were added to the cell suspension and incubated in the dark at $4{ }^{\circ} \mathrm{C}$ for $35 \mathrm{~min}$. The labeled cells were then washed in wash buffer and resuspended in $500 \mu \mathrm{l}$ PBS and subsequently analyzed on a MACSQuant Analyzer (Miltenyi Biotec, Auburn, CA, USA).

Statistical analysis. Statistical analyses were performed using Students' $t$-test. A $P$-value $<0.05$ was considered significant.

\section{Conflict of Interest}

The authors declare no conflict of interest.

Acknowledgements. We acknowledge Dr. Lorenzo Sempere for helpful discussion of topics related to miRNAs. This work was supported by a grant from the National Cancer Institute (5R01CA108539) and the United States Department of Defense Breast Cancer Research Program (W81XWH-10-1-0426) to JDR. AJD is supported by a pre-doctoral training grant from the United States Department of Defense Breast Cancer Research Program (W81XWH-11-1-0043). 
1. Hennighausen L, Robinson GW. Think globally, act locally: the making of a mouse mammary gland. Genes Dev 1998; 12: 449-455.

2. Visvader JE. Keeping abreast of the mammary epithelial hierarchy and breast tumorigenesis. Genes Dev 2009; 23: 2563-2577.

3. Shackleton M, Vaillant F, Simpson KJ, Stingl J, Smyth GK, Asselin-Labat ML et al. Generation of a functional mammary gland from a single stem cell. Nature 2006; 439: 84-88.

4. Stingl J, Eirew P, Ricketson I, Shackleton M, Vaillant F, Choi D et al. Purification and unique properties of mammary epithelial stem cells. Nature 2006; 439: 993-997.

5. Eirew P, Stingl J, Raouf A, Turashvili G, Aparicio S, Emerman JT et al. A method for quantifying normal human mammary epithelial stem cells with in vivo regenerative ability. Nat Med 2008; 14: 1384-1389.

6. Lim E, Vaillant F, Wu D, Forrest NC, Pal B, Hart AH et al. Aberrant luminal progenitors as the candidate target population for basal tumor development in BRCA1 mutation carriers. Nat Med 2009; 15: 907-913.

7. DiRenzo J, Signoretti S, Nakamura N, Rivera-Gonzalez R, Sellers W, Loda M et al. Growth factor requirements and basal phenotype of an immortalized mammary epithelial cell line. Cancer Res 2002; 62: 89-98.

8. Li H, Cherukuri P, Li N, Cowling V, Spinella M, Cole M et al. Nestin is expressed in the basal/myoepithelial layer of the mammary gland and is a selective marker of basal epithelial breast tumors. Cancer Res 2007; 67: 501-510.

9. Li N, Singh S, Cherukuri P, Li H, Yuan Z, Ellisen LW et al. Reciprocal intraepithelial interactions between TP63 and hedgehog signaling regulate quiescence and activation of progenitor elaboration by mammary stem cells. Stem Cells 2008; 26: 1253-1264.

10. Mills AA, Zheng B, Wang XJ, Vogel H, Roop DR, Bradley A. p63 is a p53 homologue required for limb and epidermal morphogenesis. Nature 1999; 398: 708-713.

11. Senoo M, Pinto F, Crum CP, McKeon F. p63 is essential for the proliferative potential of stem cells in stratified epithelia. Cell 2007; 129: 523-536.

12. Yang A, Schweitzer R, Sun D, Kaghad M, Walker N, Bronson RT et al. p63 is essential for regenerative proliferation in limb, craniofacial and epithelial development. Nature 1999; 398: $714-718$.

13. Keyes WM, Pecoraro M, Aranda V, Vernersson-Lindahl E, Li W, Vogel $\mathrm{H}$ et al. DeltaNp63alpha is an oncogene that targets chromatin remodeler Lsh to drive skin stem cell proliferation and tumorigenesis. Cell Stem Cell 2011; 8: 164-176.

14. Jung MS, Yun J, Chae HD, Kim JM, Kim SC, Choi TS et al. p53 and its homologues, p63 and $\mathrm{p} 73$, induce a replicative senescence through inactivation of NF-Y transcription factor. Oncogene 2001; 20: 5818-5825.

15. Keyes WM, Wu Y, Vogel H, Guo X, Lowe SW, Mills AA. p63 deficiency activates a program of cellular senescence and leads to accelerated aging. Genes Dev 2005; 19: 1986-1999.

16. Leong CO, Vidnovic N, DeYoung MP, Sgroi D, Ellisen LW. The p63/p73 network mediates chemosensitivity to cisplatin in a biologically defined subset of primary breast cancers. $J$ Clin Invest 2007; 117: 1370-1380.

17. Rocco JW, Leong CO, Kuperwasser N, DeYoung MP, Ellisen LW. p63 mediates survival in squamous cell carcinoma by suppression of p73-dependent apoptosis. Cancer Cell 2006; 9: 45-56.

18. Bartel DP. MicroRNAs: genomics, biogenesis, mechanism, and function. Cell 2004; 116: 281-297.

19. Ivey KN, Srivastava D. MicroRNAs as regulators of differentiation and cell fate decisions. Cell stem cell 2010; 7: 36-41.

20. Gangaraju VK, Lin H. MicroRNAs: key regulators of stem cells. Nat Rev Mol Cell Biol 2009; 10: $116-125$.

21. Lena AM, Shalom-Feuerstein R, Rivetti di Val Cervo P, Aberdam D, Knight RA, Melino G et al. miR-203 represses 'stemness' by repressing DeltaNp63. Cell Death Differ 2008; 15: 1187-1195.

22. Yi R, Poy MN, Stoffel M, Fuchs E. A skin microRNA promotes differentiation by repressing 'stemness'. Nature 2008; 452: 225-229.

23. Iorio MV, Visone R, Di Leva G, Donati V, Petrocca F, Casalini P et al. MicroRNA signatures in human ovarian cancer. Cancer Res 2007; 67: 8699-8707.

24. Greither T, Grochola LF, Udelnow A, Lautenschlager C, Wurl P, Taubert H. Elevated expression of microRNAs 155, 203,210 and 222 in pancreatic tumors is associated with poorer survival. Int J Cancer 2010; 126: 73-80.

25. Schetter AJ, Leung SY, Sohn JJ, Zanetti KA, Bowman ED, Yanaihara N et al. MicroRNA expression profiles associated with prognosis and therapeutic outcome in colon adenocarcinoma. JAMA 2008; 299: 425-436.

26. Furuta M, Kozaki KI, Tanaka S, Arii S, Imoto I, Inazawa J. miR-124 and miR-203 are epigenetically silenced tumor-suppressive microRNAs in hepatocellular carcinoma. Carcinogenesis 2010; 31: 766-776.

27. Saini S, Majid S, Yamamura S, Tabatabai L, Suh SO, Shahryari V et al. Regulatory role of mir203 in prostate cancer progression and metastasis. Clin Cancer Res 2011; 17: 5287-5298.

28. Garofalo M, Romano G, Di Leva G, Nuovo G, Jeon YJ, Ngankeu A et al. EGFR and MET receptor tyrosine kinase-altered microRNA expression induces tumorigenesis and gefitinib resistance in lung cancers. Nat Med 2012; 18: 74-82.

29. Aigner K, Dampier B, Descovich L, Mikula M, Sultan A, Schreiber M et al. The transcription factor ZEB1 (deltaEF1) promotes tumour cell dedifferentiation by repressing master regulators of epithelial polarity. Oncogene 2007; 26: 6979-6988.

30. Burk U, Schubert J, Wellner U, Schmalhofer O, Vincan E, Spaderna S et al. A reciprocal repression between ZEB1 and members of the miR-200 family promotes EMT and invasion in cancer cells. EMBO Rep 2008; 9: 582-589.

31. Thiery JP, Acloque H, Huang RY, Nieto MA. Epithelial-mesenchymal transitions in development and disease. Cell 2009; 139: 871-890.

32. Blick T, Hugo H, Widodo E, Waltham M, Pinto C, Mani SA et al. Epithelial mesenchymal transition traits in human breast cancer cell lines parallel the CD44(hi/)CD24 (lo/-) stem cell phenotype in human breast cancer. J Mammary Gland Biol Neoplasia 2010; 15: 235-252.

33. Chang CJ, Chao $\mathrm{CH}$, Xia W, Yang JY, Xiong Y, Li CW et al. p53 regulates epithelialmesenchymal transition and stem cell properties through modulating miRNAs. Nat Cell Biol 2011; 13: 317-323.

34. Mani SA, Guo W, Liao MJ, Eaton EN, Ayyanan A, Zhou AY et al. The epithelial-mesenchymal transition generates cells with properties of stem cells. Cell 2008; 133: 704-715.

35. Vaillant F, Asselin-Labat ML, Shackleton M, Forrest NC, Lindeman GJ, Visvader JE. The mammary progenitor marker CD61/beta3 integrin identifies cancer stem cells in mouse models of mammary tumorigenesis. Cancer Res 2008; 68: 7711-7717.

36. Asselin-Labat ML, Sutherland KD, Barker H, Thomas R, Shackleton M, Forrest NC et al. Gata-3 is an essential regulator of mammary-gland morphogenesis and luminal-cell differentiation. Nat Cell Biol 2007; 9: 201-209.

37. Kouros-Mehr H, Slorach EM, Sternlicht MD, Werb Z. GATA-3 maintains the differentiation of the luminal cell fate in the mammary gland. Cell 2006; 127: 1041-1055.

38. Wellner U, Schubert J, Burk UC, Schmalhofer O, Zhu F, Sonntag A et al. The EMTactivator ZEB1 promotes tumorigenicity by repressing stemness-inhibiting microRNAs. Nat Cell Biol 2009; 11: 1487-1495.

39. Borrelli S, Candi E, Hu B, Dolfini D, Ravo M, Grober OM et al. The p63 target HBP1 is required for skin differentiation and stratification. Cell Death Differ 2010; 17: 1896-1907.

40. Yao CJ, Works K, Romagnoli PA, Austin GE. Effects of overexpression of HBP1 upon growth and differentiation of leukemic myeloid cells. Leukemia 2005; 19: 1958-1968.

41. Danielson KG, Oborn CJ, Durban EM, Butel JS, Medina D. Epithelial mouse mammary cell line exhibiting normal morphogenesis in vivo and functional differentiation in vitro. Proc Natl Acad Sci USA 1984; 81: 3756-3760.

42. Dontu G, Abdallah WM, Foley JM, Jackson KW, Clarke MF, Kawamura MJ et al. In vitro propagation and transcriptional profiling of human mammary stem/progenitor cells. Genes Dev 2003; 17: 1253-1270.

43. Al-Hajj M, Wicha MS, Benito-Hernandez A, Morrison SJ, Clarke MF. Prospective identification of tumorigenic breast cancer cells. Proc Natl Acad Sci USA 2003; 100: 3983-3988.

44. Shipitsin M, Campbell LL, Argani P, Weremowicz S, Bloushtain-Qimron N, Yao J et al. Molecular definition of breast tumor heterogeneity. Cancer Cell 2007; 11: 259-273.

45. Nguyen DH, Oketch-Rabah HA, Illa-Bochaca I, Geyer FC, Reis-Filho JS, Mao JH et al. Radiation acts on the microenvironment to affect breast carcinogenesis by distinct mechanisms that decrease cancer latency and affect tumor type. Cancer Cell 2011; 19: 640-651.

46. Paulson KE, Rieger-Christ K, McDevitt MA, Kuperwasser C, Kim J, Unanue VE et al. Alterations of the HBP1 transcriptional repressor are associated with invasive breast cancer. Cancer Res 2007; 67: 6136-6145.

47. Escamilla-Powers JR, Daniel CJ, Farrell A, Taylor K, Zhang X, Byers S et al. The tumor suppressor protein HBP1 is a novel c-myc-binding protein that negatively regulates c-myc transcriptional activity. J Biol Chem 2010; 285: 4847-4858.

48. Sampson EM, Haque ZK, Ku MC, Tevosian SG, Albanese C, Pestell RG et al. Negative regulation of the Wnt-beta-catenin pathway by the transcriptional repressor HBP1. EMBO J 2001; 20: 4500-4511.

49. Aydogdu E, Katchy A, Tsouko E, Lin CY, Haldosen LA, Helguero L et al. MicroRNAregulated gene networks during mammary cell differentiation are associated with breast cancer. Carcinogenesis 2012; 33: 1502-1511.

50. Castilla MA, Moreno-Bueno G, Romero-Perez L, Van De Vijver K, Biscuola M, LopezGarcia MA et al. Micro-RNA signature of the epithelial-mesenchymal transition in endometrial carcinosarcoma. J Pathol 2011; 223: 72-80.

51. Polyak K, Weinberg RA. Transitions between epithelial and mesenchymal states: acquisition of malignant and stem cell traits. Nat Rev Cancer 2009; 9: 265-273.

52. Spaderna S, Schmalhofer O, Wahlbuhl M, Dimmler A, Bauer K, Sultan A et al. The transcriptional repressor ZEB1 promotes metastasis and loss of cell polarity in cancer. Cancer Res 2008; 68: 537-544.

53. Baffa R, Fassan M, Volinia S, O'Hara B, Liu CG, Palazzo JP et al. MicroRNA expression profiling of human metastatic cancers identifies cancer gene targets. J Pathol 2009; 219: 214-221.

54. Li N, Li H, Cherukuri P, Farzan S, Harmes DC, DiRenzo J. TA-p63-gamma regulates expression of DeltaN-p63 in a manner that is sensitive to p53. Oncogene 2006; 25: 2349-2359.

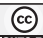

SOMERISHTS

published by Nature Publishing Group. This work is licensed under the Creative Commons Attribution-NonCommercial-No Derivative Works 3.0 Unported License. To view a copy of this license, visit http://creativecommons.org/licenses/by-nc-nd/3.0/ 